\title{
Identification of a Novel Endocannabinoid-Hydrolyzing Enzyme Expressed by Microglial Cells
}

\author{
Giulio G. Muccioli, ${ }^{1}$ Cong Xu, ${ }^{1}$ Emma Odah, ${ }^{1}$ Eiron Cudaback, ${ }^{1}$ Jose Antonio Cisneros, ${ }^{3}$ Didier M. Lambert, ${ }^{4}$ \\ María Luz López Rodríguez, ${ }^{3}$ Sandra Bajjalieh, ${ }^{1}$ and Nephi Stella ${ }^{1,2}$ \\ Departments of ${ }^{1}$ Pharmacology and ${ }^{2}$ Psychiatry and Behavioral Sciences, University of Washington, Seattle, Washington 98195-7280, ${ }^{3}$ Departamento de \\ Quimica Organica I, Facultad de Ciencias Quimicas, Universidad Complutense, E-28040 Madrid, Spain, and ${ }^{4}$ Drug Design and Discovery Center and Unité \\ de Chimie Pharmaceutique et de Radiopharmacie, Université catholique de Louvain, B-1200 Brussels, Belgium
}

The endocannabinoids (eCBs) anandamide and 2-arachidonoyl glycerol (2-AG) are inactivated by a two-step mechanism. First, they are carried into cells, and then anandamide is hydrolyzed by fatty acid amide hydrolase (FAAH) and 2-AG by monoacylglycerol lipase (MGL). Here we provide evidence for a previously undescribed MGL activity expressed by microglial cells. We found that the mouse microglial cell line BV-2 does not express MGL mRNA and yet efficiently hydrolyzes 2-AG. URB597 (3'-carbamoyl-biphenyl-3-ylcyclohexylcarbamate) reduces this hydrolysis by $50 \%$, suggesting the involvement of FAAH. The remaining activity is blocked by classic MGL inhibitors [[1,1-biphenyl]-3-yl-carbamic acid, cyclohexyl ester (URB602) and MAFP (methylarachidonyl fluorophosphate)] and is unaffected by inhibitors of COXs (cyclooxygenases), LOXs (lipooxygenases), and DGLs (diacylglycerol lipases), indicating the involvement of a novel MGL activity. Accordingly, URB602 leads to selective accumulation of 2-AG in intact BV-2 cells. Although MGL expressed in neurons is equally distributed between the cytosolic, mitochondrial, and nuclear fractions, the novel MGL activity expressed by BV-2 cells is enriched in mitochondrial and nuclear fractions. A screen for novel inhibitors of eCB hydrolysis identified several compounds that differentially block MGL, FAAH, and the novel MGL activity. Finally, we provide evidence for expression of the novel MGL by mouse primary microglia in culture. Our results suggest the presence of a novel, pharmacologically distinct, MGL activity that controls 2-AG levels in microglia.

Key words: lipase; lipid; $\mathrm{CB}_{1}$ receptor; $\mathrm{CB}_{2}$ receptor; signaling; 2-arachidonoyl glycerol

\section{Introduction}

Endocannabinoids (eCBs) are lipid transmitters that are released from their membrane precursors by lipases and activate cannabinoid receptors and are then inactivated by uptake followed by hydrolysis. Anandamide (AEA) is released from its membrane precursor by various lipases and hydrolases (Okamoto et al., 2004; Sun et al., 2004; Leung et al., 2006; Liu et al., 2006; Simon and Cravatt, 2006), activates cannabinoid receptors as a partial agonist, and is inactivated by uptake followed by fatty acid amide hydrolase (FAAH)-mediated hydrolysis (Cravatt and Lichtman, 2003; Freund et al., 2003). In contrast, 2-arachidonoyl glycerol (2-AG) is released from its membrane precursor by phospholipase C and diacylglycerol lipase (DGL) (Stella et al., 1997; Bisogno et al., 2003; Maejima et al., 2005), activates cannabinoid receptors as a full agonist, and is inactivated by uptake followed

Received Nov. 6, 2006; revised Jan. 26, 2007; accepted Feb. 1, 2007.

This work was supported by National Institute on Drug Abuse Grants DA022469 and DA014486 (N.S.), a Université catholique de Louvain Fonds Spécial de Recherché grant (D.M.L.), Belgian National Funds for Scientific Research Grant 3.4.581.06 F (D.M.L.), and Ministerio de Educacion y Ciencia SAF2004-07103-C02-01 (M.L.L.R.).

Correspondence should be addressed to Nephi Stella, Departments of Pharmacology and Psychiatry and Behavioral Sciences, Health Sciences Center, BB-1538c, University of Washington, 1959 NE Pacific Street, Seattle, WA 98195-7280. E-mail: nstella@u.washington.edu.

DOI:10.1523/JNEUROSCI.4830-06.2007

Copyright $\odot 2007$ Society for Neuroscience $\quad$ 0270-6474/07/272883-07\$15.00/0 by monoacylglycerol lipase (MGL)-mediated hydrolysis (Freund et al., 2003).

The balance between $\mathrm{eCB}$ production and inactivation determines the extent of eCB accumulation in tissue and allied cannabinoid receptor activation. Thus, compounds inhibiting FAAH or MGL lead to accumulation of anandamide or 2-AG and partial or full activation of cannabinoid receptors, respectively. Several selective FAAH and MGL inhibitors that lead to enhanced anandamide or 2-AG levels have been reported. Systemic injection of the FAAH inhibitor 3'-carbamoyl-biphenyl-3-yl-cyclohexylcarbamate (URB597) leads to anandamide accumulation in brain without affecting 2-AG levels (Fegley et al., 2005). This selective accumulation of anandamide relieves signs of anxiety and depression in mice undergoing distress and reduces inflammation-induced pain and autoimmune-mediated cell damage, without inducing $\mathrm{CB}_{1}$ (cannabinoid 1 receptor)-mediated adverse effects (Baker et al., 2001; Kathuria et al., 2003; Cravatt et al., 2004; Gobbi et al., 2005). Systemic injection of the MGL inhibitor URB602 leads to 2-AG accumulation in the dorsal midbrain without affecting anandamide levels. This selective accumulation of 2-AG mimics stress-related analgesia, also without inducing adverse effects (Hohmann et al., 2005). This evidence suggests that inhibition of specific eCB-hydrolyzing enzymes constitutes a promising therapeutic approach to relieve discrete symptoms without producing side effects. 
Although a large amount of data is available on FAAH [from its crystal structure to the chemical platform required for its selective inhibition (McKinney and Cravatt, 2005)], much less is known about 2-AG hydrolysis and MGL. MGL was initially purified, and its cDNA was isolated and cloned from adipose tissue (Tornqvist and Belfrage, 1976; Karlsson et al., 1997). This $33 \mathrm{Kd}$ protein contains two lipase motifs (active serine motif GXSCG and the HG dipeptide) and is abundant in brain tissue, particularly at presynaptic terminals (Karlsson et al., 1997; Gulyas et al., 2004). Adenovirus-mediated expression of MGL in cultured neurons enhances 2-AG hydrolysis and reduces activity-dependent accumulation of 2-AG, suggesting that MGL constitutes a ratelimiting step of 2-AG accumulation in neurons (Dinh et al., 2002). Accordingly, pharmacological inhibition of MGL leads to 2-AG accumulation in neural tissue and enhances its cannabimimetic effects (Makara et al., 2005). Additional enzymes have been shown to metabolize 2-AG, including cyclooxygenase (COX), lipooxygenase (LOX), DGL, and FAAH (Mentlein et al., 1984; Somma-Delpéro et al., 1995; Goparaju et al., 1998; Kozak et al., 2000; Dinh et al., 2004). Because 2-AG degradation appears to be complex and involve multiple enzymes and could vary between cell types, we sought to compare 2-AG hydrolysis in neurons and microglia.

\section{Materials and Methods}

Materials. Nordihydroguaiaretic acid, URB597, URB602, methylarachidonyl fluorophosphate (MAFP), 2-AG, and $\mathrm{d}_{5}-2-\mathrm{AG}$ were from Cayman Chemical (Ann Arbor, MI). [ $\left.{ }^{3} \mathrm{H}\right]-2-\mathrm{AG}$ and $\left[{ }^{3} \mathrm{H}\right]$-anandamide (radiolabel on their glycerol and ethanolamine moieties, respectively) were from American Radiolabeled Chemicals (St. Louis, MO) and the National Institute on Drug Abuse drug supply system. Tetrahydrolipstatin, acetylsalicylic acid, ibuprofen, indomethacin, and PMSF were from Sigma (St. Louis, MO). Anandamide and $\mathrm{d}_{4}$-anandamide were synthesized in the laboratory (Walter et al., 2002).

Cell culture. BV-2 cells were expanded as described previously (Walter et al., 2003) and serum-deprived by transferring them to MEM supplemented with $1 \mathrm{~mm}$ glutamine, $10 \mathrm{~mm}$ HEPES, $10 \mathrm{~mm} \mathrm{NaHCO}{ }_{3}, 100 \mathrm{U} / \mathrm{ml}$ penicillin, $100 \mu \mathrm{g} / \mathrm{ml}$ streptomycin, and $10 \%$ CellGro for $12 \mathrm{~h}$. Mouse neurons in primary culture were prepared according to the guidelines of the Institutional Animal Care and Use Committee of the University of Washington as described previously (Stella et al., 1995). Briefly, 1-d-old mice pups $(\mathrm{C} 57 \mathrm{BL} / 6)$ were killed, and their cerebral cortices were dissected. Cortices were cut and incubated with papain $(40 \mathrm{U} / \mathrm{ml})$ for 30 min, centrifuged, and resuspended in Neurobasal medium. Tissues were then mechanically dissociated using a flame-polished Pasteur pipette and passed through a sieve. Cells were seeded in Neurobasal, B27 (2\%), Glutamax (1\%), and penicillin-streptomycin $(10 \mathrm{U} / \mathrm{ml}$ and $10 \mu \mathrm{g} / \mathrm{ml}$, respectively) at a density of $2 \times 10^{6}$ cells per $100 \mathrm{~mm}$ dish (Corning, Lowell, MA) precoated with $1 \mu \mathrm{g} / \mathrm{ml}$ poly-L-ornithine. Neurons were used after $7 \mathrm{~d}$ in culture. Mouse microglia in culture were prepared as described previously (Walter et al., 2002). Briefly, dissociated cells were prepared as above but seeded in DMEM supplemented with FBS (10\%). Floating microglia were recovered weekly and plated at a density of $5 \times$ $10^{5}$ cells per $100 \mathrm{~mm}$ dish (uncoated; Corning). After $1-2 \mathrm{~h}$, shaking the dish and rinsing once with PBS removed nonattached cell. The remaining attached microglia were incubated for $18-24 \mathrm{~h}$ in MEM CellGro before preparing cell homogenates (see below).

Reverse transcription-PCR. Reverse transcription (RT) was performed using superscript first-strand synthesis (Invitrogen, Carlsbad, CA). PCR was performed using the following primers: "Full MGL," forward, 5'-GGCGAACTCCACAGAATGTT-3' and reverse, 5'-ACTTGGAAGTCCGACACCAC-3'; "catalytic MGL," forward, 5'-AGGTGAAATCAGGACCATGC-3' and reverse, 5'-GGAGAGAGGATGGTGGTGTC-3'; FAAH, forward, 5'TGTGTGGTGGTGCAGGTACT-3' and reverse, 5' -CTGCACTGCTGTCTGTCCAT-3'; GAPDH, 5'-ATGACATCAAGAAGGTGGTG-3' and reverse, 5'-CATACCAGGAAATGAGCTTG-3'. Amplicons were separated on agarose gels and visualized using ethidium-bromide. Absence of RTPCR product in the "no RT" reaction was systematically verified to confirm the lack of genomic DNA in samples (data not shown).

Homogenate preparation and measurement of $\left[{ }^{3} \mathrm{H}\right]-2-A G$ and $\left[{ }^{3} \mathrm{H}\right]-$ anandamide hydrolysis. BV-2 cells $\left(8 \times 10^{6}\right)$ or $2 \times 10^{6}$ neurons (in 100 $\mathrm{mm}$ dishes) were rinsed once with PBS, lysed in $1 \mathrm{ml}$ of ice-cold HEPES (250 mM)-sucrose (10 mM) buffer, $\mathrm{pH} 7.4$, and homogenized on ice using a Dounce tissue homogenizer. Homogenates ( $20 \mu \mathrm{g}$ of proteins in $400 \mu \mathrm{l}$ of Tris $\mathrm{HCl}(100 \mathrm{~mm}, \mathrm{pH}$ 7.4) were added to silanized glass tubes containing either $0.5 \mu \mathrm{l}$ of drug in DMSO or DMSO alone $(0.1 \%$, control). Hydrolysis was initiated by adding $100 \mu \mathrm{l}$ of $\left[{ }^{3} \mathrm{H}\right]-2-\mathrm{AG}(1.25 \mathrm{nM}$, $\approx 55,000 \mathrm{dpm})$ or $\left[{ }^{3} \mathrm{H}\right]$-anandamide $(0.8 \mathrm{~nm}, \approx 50,000 \mathrm{dpm})$ in Tris $\mathrm{HCl}$ containing $0.1 \%$ fatty acid-free BSA. All additions were done using silanized pipette tips. Tubes were incubated in a shaking water bath at $37^{\circ} \mathrm{C}$. Tubes containing buffer only were used as control for chemical hydrolysis (blank) and this value was systematically subtracted. Reactions were stopped by adding $2 \mathrm{ml}$ of ice-cold $\mathrm{MeOH}-\mathrm{CHCl}_{3}(1: 1)$ and the hydrophilic products of the hydrolysis extracted by vigorous mixing and subsequent centrifugation at $800 \times g(10 \mathrm{~min})$. One milliliter of the upper layer was recovered and mixed with Ecoscint $(4 \mathrm{ml})$, and radioactivity was determined by liquid scintillation.

Subcellular fractionation. Crude homogenates were centrifuged for 5 $\min$ at $1300 \times g$ (nuclei fraction). The resulting supernatants were centrifuged for $10 \mathrm{~min}$ at $15,000 \times g$ (mitochondrial fraction), and the supernatant was further centrifuged at $100,000 \times g$ for $60 \mathrm{~min}$, resulting in the microsomal and cytosolic fractions.

Gas chromatography/mass spectrometry quantification of anandamide and 2-AG. Anandamide and 2-AG amounts in BV-2 cells $\left(3 \times 10^{6}\right.$ cells/ $100 \mathrm{~mm}$ dish) were measured as described previously, with some modifications (Walter et al., 2002; Walter and Stella, 2003). Briefly, cell media was replaced by MEM plus CellGro (10 ml). After $12 \mathrm{~h}$, drugs (MAFP, URB597, URB602, in $1 \mathrm{ml}$ ) were added to the cells for 20 min under gentle agitation in a shaking water bath at $37^{\circ} \mathrm{C}$. Media were removed, and cells were fixed with ice-cold $\mathrm{MeOH}(5 \mathrm{ml})$, and homogenate was recovered in glass vials containing 200 pmol of $d_{4}$-AEA and $d_{5}-2$-AG in $\mathrm{CHCl}_{3}(10 \mathrm{ml})$. PBS $(2.5 \mathrm{ml})$ was then added to obtain a ratio of $\mathrm{CHCl}_{3}$, $\mathrm{MeOH}$, and water of 4:2:1. The organic phase was recovered and purified by silica open-bed chromatography and quantified by isotope dilution using a chemical ionization (CI)-gas chromatography/mass spectrometry (GC/MS).

Data analysis. GraphPad (San Diego, CA) PRISM (version 4) was used to analyze the data and generate dose-response curves.

\section{Results}

We used RT-PCR to determine whether neurons and the microglia cell line BV-2 express MGL mRNA. Because the MGL gene contains seven exons that can be alternatively spliced and have different 5' leader sequences (Karlsson et al., 2001), we designed two sets of primers to unequivocally assess for the presence of MGL mRNA in these cells and rule out any alternative splicing. One set of primers was designed to amplify the full-length MGL mRNA (i.e., $870 \mathrm{bp}$ ), and the second set of primers was designed to amplify a stretch of $168 \mathrm{bp}$ that encode a crucial amino acid in the catalytic site of MGL (Karlsson et al., 1997) (Fig. 1A). Both sets of primers generated clear amplicons when using total RNA from neurons, whereas no amplicons were generated when using total RNA from BV-2 cells (Fig. $1 B$ ). We then compared the ability of neurons and BV-2 cells to hydrolyze 2-AG. Whole-cell homogenates prepared from neurons hydrolyzed $\left[{ }^{3} \mathrm{H}\right]-2-\mathrm{AG}$ with a specific activity of $12.5 \mathrm{pmol} / \mathrm{min} / \mathrm{mg}$ protein. This activity started to saturate at $5 \mu \mathrm{g}$ of protein but remained linear for at least $10 \mathrm{~min}$ of incubation when using $1 \mu \mathrm{g}$ of protein (supplemental Fig. $1 A, B$, available at www.jneurosci.org as supplemental material). Under these linear conditions, unlabeled 2-AG competed for $\left[{ }^{3} \mathrm{H}\right]-2-\mathrm{AG}$ hydrolysis with an $\mathrm{IC}_{50}$ of $0.6 \mu \mathrm{M}$ (supplemental Fig. $1 C$, available at www.jneurosci.org as supplemental material). Whole-cell homogenates prepared from BV-2 cells 

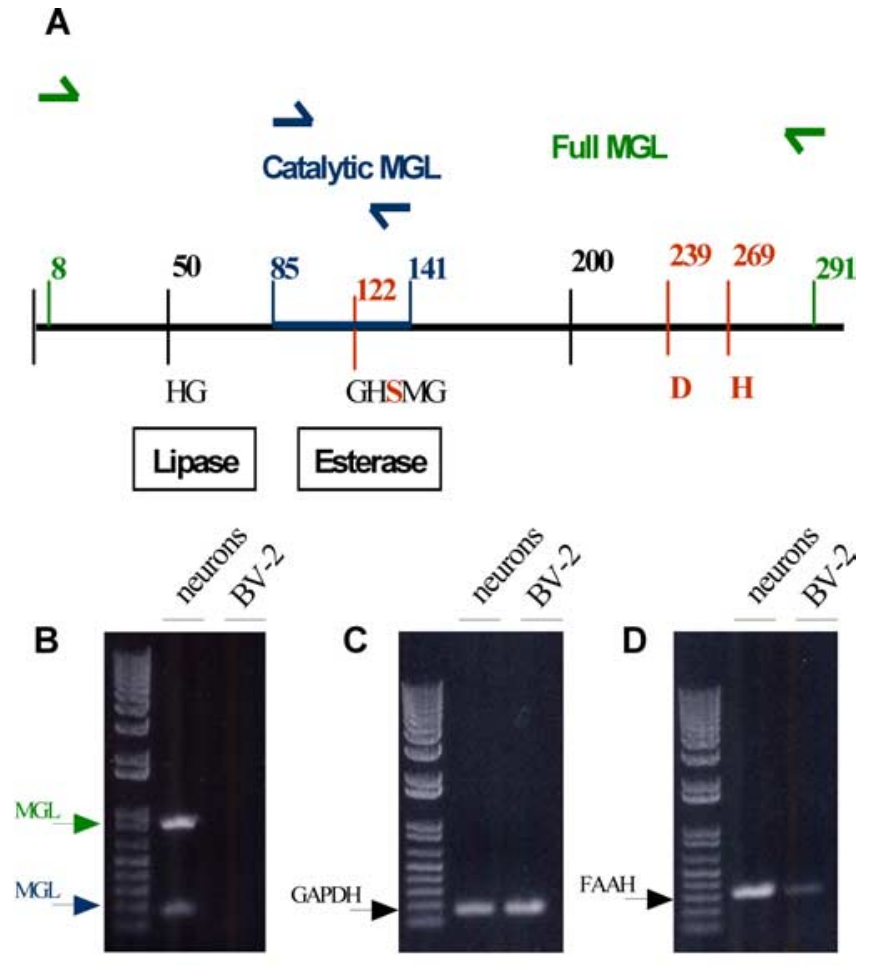

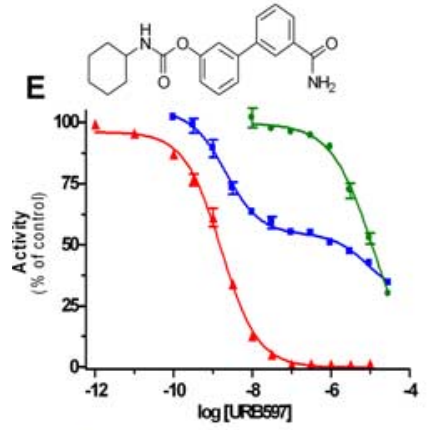

[ ${ }^{3}$ ]-2-AGhydrolysis by BV-2

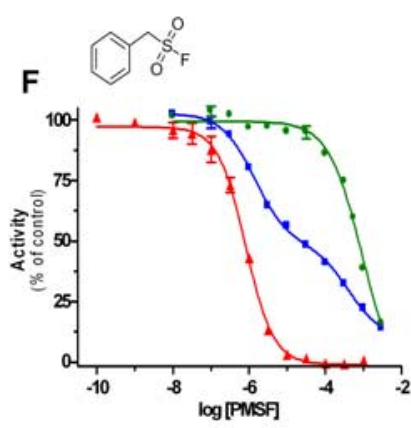

- [H]-2-AGhydrolysis by neurons

\section{A [H]-AEA hydrolysis by BV-2}

Figure 1. BV-2 cells do not express MGL and yet hydrolyze 2-AG: partial involvement of FAAH. A, Scheme of MGL sequence. The predicted PCR amplicons (Full MGL and Catalytic MGL) are shown. The residues of the putative catalytic triad (bold red) (Karlsson et al., 1997), the HG dipeptide, and the active site serine motif GXSXG are indicated. $\boldsymbol{B}-\boldsymbol{D}, \mathrm{RT}-\mathrm{PCR}$ from neurons and $B V-2$ mRNA were performed with primers recognizing mouse MGL $(\boldsymbol{B}$, in green, full MGL, 870 bp; in red, catalytic MGL, 168 bp) or FAAH mRNA (D, 330 bp). C, GAPDH was used as positive control. $\boldsymbol{E}, \boldsymbol{F}$, Effect of increasing concentrations of the FAAH inhibitors URB597 (E) and PMSF $(\boldsymbol{F})$ on [ $\left.{ }^{3} \mathrm{H}\right]-2-\mathrm{AG}$ hydrolysis by BV-2 ([ $\left.{ }^{3} \mathrm{H}\right]-2-\mathrm{AG}$ by BV-2; blue) and primary neuron $\left(\left[{ }^{3} \mathrm{H}\right]-2-\mathrm{AG}\right.$ by neurons; green) homogenate and on $\left[{ }^{3} \mathrm{H}\right]-\mathrm{AEA}$ hydrolysis by BV-2 ([ $\left.{ }^{3} \mathrm{H}\right]-\mathrm{AEA}$ by $\mathrm{BV}-2$; red) homogenate. Values are mean \pm SEM (3 experiments performed in duplicate) and are expressed as percentage of control.

hydrolyzed $\left[{ }^{3} \mathrm{H}\right]-2-\mathrm{AG}$ with a specific activity of $1.2 \mathrm{pmol} /$ $\mathrm{min} / \mathrm{mg}$ protein. This activity started to saturate at $35 \mu \mathrm{g}$ of protein but remained linear for at least $10 \mathrm{~min}$ of incubation when using $20 \mu$ g of protein (supplemental Fig. $1 D, E$, available at www. jneurosci.org as supplemental material). Under these linear conditions, unlabeled 2-AG competed for $\left[{ }^{3} \mathrm{H}\right]-2-A G$ hydrolysis with an $\mathrm{IC}_{50}$ of $1.1 \mu \mathrm{M}$ (supplemental Fig. $1 F$, available at www. jneurosci.org as supplemental material). These results show that BV-2 cells hydrolyze 2-AG in the absence of MGL, although with lower efficacy than MGL-expressing neurons.

To identify the enzyme responsible for 2-AG hydrolysis in
BV-2 cells, we tested the effect of inhibitors of COX, LOX, DGL, and FAAH, because these enzymes can also use 2-AG as substrate (Goparaju et al., 1998; Kozak et al., 2000; Moody et al., 2001; Kozak et al., 2002). Highly efficacious inhibitors of COX, LOX, and DGL did not affect $\left[{ }^{3} \mathrm{H}\right]-2-\mathrm{AG}$ hydrolysis by BV-2 cells, ruling out their involvement in this activity (Table 1). However, several lines of evidence suggested that FAAH is responsible for approximately one-half of the 2-AG hydrolysis occurring in BV-2 cell homogenate. First, BV-2 cells express functional FAAH because they express FAAH mRNA (Fig. 1D), and their homogenate hydrolyzed $\left[{ }^{3} \mathrm{H}\right]$-anandamide in a time- and proteindependent manner, yielding a specific activity of $0.4 \mathrm{pmol} /$ $\mathrm{min} / \mathrm{mg}$ protein. Unlabeled anandamide entirely blocked $\left[{ }^{3} \mathrm{H}\right]$ anandamide hydrolysis with an $\mathrm{IC}_{50}$ of $0.5 \mu \mathrm{M}$ (supplemental Fig. $1 G-I$, available at www.jneurosci.org as supplemental material). Furthermore, two FAAH inhibitors, URB597 and PMSF, entirely blocked $\left[{ }^{3} \mathrm{H}\right]$-anandamide hydrolysis with $\mathrm{IC}_{50}$ values similar to those reported for FAAH (1.6 nM and $0.8 \mu \mathrm{M}$, respectively) (Fig. $1 E, F)$ (Goparaju et al., 1998; Kathuria et al., 2003). This result suggests that $\left[{ }^{3} \mathrm{H}\right]$-anandamide hydrolysis in BV-2 cells is entirely attributable to FAAH. Confirming the specificity of URB597 and PMSF at FAAH, only much higher concentrations of these compounds inhibited MGL-mediated $\left[{ }^{3} \mathrm{H}\right]-2-A G$ hydrolysis by neurons ( $\mathrm{IC}_{50}$ values of 11.9 and $918 \mu \mathrm{M}$, respectively) (Fig. 1E,F). When testing URB597 and PMSF on $\left[{ }^{3} \mathrm{H}\right]-2-\mathrm{AG}$ hydrolysis by BV-2 cell homogenate, we found that both of these compounds inhibited this activity in a biphasic manner. Approximately one-half of 2-AG hydrolysis by BV-2 cells was inhibited by URB597 and PMSF with low $\mathrm{IC}_{50}$ values that were within the range of what we found for FAAH ( IC $_{50}$ values of $2.1 \mathrm{nM}$ and 1.4 $\mu \mathrm{M}$, respectively). The other half of $2-\mathrm{AG}$ hydrolysis was inhibited with much higher $\mathrm{IC}_{50}$ values ( 8.6 and $408 \mu \mathrm{M}$, respectively), which were within the range of what we found for MGL expressed by neurons (Fig. $1 E, F$ ). These data suggest that FAAH accounts for one-half of the 2-AG hydrolysis in BV-2 cell homogenate, whereas none of the enzymes known to hydrolyze 2-AG, namely MGL, COX, LOX, and DGL, can account for the other half of this activity. They also suggest that BV-2 cells express a 2-AGhydrolyzing activity that has the same low sensitivity to URB597 and PMSF as MGL expressed by neurons. For sake of clarity, we will refer to this 2-AG-hydrolyzing activity expressed by BV-2 cells as "novel MGL."

To further characterize the novel MGL activity expressed by BV-2 cells, we tested the effect of two classic MGL inhibitors, MAFP and URB602, using $\left[{ }^{3} \mathrm{H}\right]-2-A G$ hydrolysis by neurons and $\left[{ }^{3} \mathrm{H}\right]$-anandamide hydrolysis by BV-2 cells as reference for MGL and FAAH, respectively. MAFP inhibited $\left[{ }^{3} \mathrm{H}\right]-2-\mathrm{AG}$ hydrolysis by BV-2 cells in a biphasic manner ( $\mathrm{IC}_{50}$ of 0.1 and $33 \mathrm{nM}$ ), and $\left[{ }^{3} \mathrm{H}\right]-2-A G$ hydrolysis by neurons and $\left[{ }^{3} \mathrm{H}\right]$-anandamide hydrolysis by BV-2 cells in monophasic manners $\left(\mathrm{IC}_{50}\right.$ values of 0.2 and $0.1 \mathrm{nM}$, respectively) (Fig. 2A). URB602 also inhibited $\left[{ }^{3} \mathrm{H}\right]-2-$ AG hydrolysis by BV-2 in a biphasic manner $\left(\mathrm{IC}_{50} 7.2 \mu \mathrm{M}\right.$ and 7.6 $\mathrm{mm})$ and $\left[{ }^{3} \mathrm{H}\right]-2-\mathrm{AG}$ hydrolysis by neurons and $\left[{ }^{3} \mathrm{H}\right]-$ anandamide hydrolysis by BV-2 cells in a monophasic manner $\left(\mathrm{IC}_{50}\right.$ values of 5.0 and $4.5 \mu \mathrm{M}$, respectively) (Fig. $2 \mathrm{~B}$ ). These results confirm the involvement of FAAH in one-half of the 2-AG hydrolysis measured in BV-2 cell homogenate. They also show that the novel MGL expressed by BV-2 cells is sensitive to MAFP and URB602 but to a lesser extent than MGL expressed by neurons.

Next, we used the same pharmacological approach to determine whether mouse primary microglia in culture also express the novel MGL. Whole-cell homogenates prepared from these 
cells hydrolyzed $\left[{ }^{3} \mathrm{H}\right]-2-\mathrm{AG}$ in a proteindependent manner (supplemental Fig. 1J, available at www.jneurosci.org as supplemental material). Under linear conditions (10 $\mu$ g of protein), we found that this activity was inhibited in a biphasic manner by four inhibitors (namely MAFP, PMSF, URB602, and URB597), with $\mathrm{IC}_{50}$ values similar to what we had found in BV-2 cells (Fig. 3). Thus, similarly to BV-2 cells, both FAAH and the novel MGL mediate 2-AG hydrolysis in primary microglia homogenated.

To develop inhibitors capable of discriminating between MGL, FAAH, and the novel MGL activity, we screened a library of 66 compounds (supplemental table, available at www.jneurosci.org as supplemental material). In this library, we can distinguish three main chemotypes that can lead to different mechanisms of action: (1) esters, amides, and isosters (such as thioamides, which presumably will compete with the substrate); (2) carbamates, which can inhibit the enzyme in an irreversible and covalent manner; and (3) maleimides and disulfide derivatives, which will react with free thiol groups in the protein. Each compound was initially tested at $10 \mu \mathrm{M}$ on $\left[{ }^{3} \mathrm{H}\right]-2-\mathrm{AG}$ hydrolysis by BV-2 cell homogenate (supplemental table, available at www.jneurosci.org as supplemental material), and the full dose-responses of our most promising and interesting compounds are shown in Figure $2 C-F$. Compound 49 (a thiuram disulfide, known to react with cysteine residues) inhibited MGL expressed by neurons more potently $\left(\mathrm{IC}_{50}\right.$ of $\left.7.7 \mu \mathrm{M}\right)$ than the novel MGL and FAAH activities expressed by BV-2 cells ( $\mathrm{IC}_{50}$ values of 21 and $34 \mu \mathrm{M}$, respectively) (Fig. 2C). Compound 15 [a carbamate related to URB597 (Tarzia et al., 2003)] inhibited FAAH expressed by BV-2 cells and MGL expressed by neurons in a monophasic manner $\left(\mathrm{IC}_{50}\right.$ values of 19 $\mathrm{nm}$ and $6.4 \mu \mathrm{M}$, respectively) and inhibited $\left[{ }^{3} \mathrm{H}\right]-2-\mathrm{AG}$ hydrolysis by BV-2 cells in a biphasic manner $(32 \mathrm{~nm}$ and $6.6 \mu \mathrm{M}$, respectively) (Fig. 2D). Compound 40 (an arachidonoyl ester derivative) inhibited all three enzymatic activities with similar $\mathrm{IC}_{50}$ values (7-12 $\mu \mathrm{M})$ (Fig. 2E), whereas its analog, compound 38 (a palmitoleoyl ester derivative), was more potent on FAAH and the novel MGL activity expressed by BV-2 cells than on MGL expressed by neurons (Fig. $2 F$ ). These results show that MGL, FAAH, and the novel MGL activity have distinct pharmacological profiles.

Enzymatic activities responsible for 2-AG hydrolysis have different subcellular distributions depending on species and tissue. For example, in rat cerebellum, 2-AG hydrolysis is enriched in the membrane fraction (Ghafouri et al., 2004), whereas in porcine cerebellum it is equally distributed between the membrane and cytosolic fractions (Goparaju et al., 1999). In rat macrophages, 2-AG hydrolysis is enriched in the cytosolic fraction (Di Marzo et al., 1999). We prepared subcellular fractions from neurons and found that its MGL activity was equally distributed between the nuclear, mitochondrial, microsomal, and cytosolic fractions. For BV-2 cells, we found that the novel MGL activity was enriched in the mitochondrial and nuclear fractions (Fig. 4). When testing the effect of MAFP on BV-2 mitochondrial fractions, we found a biphasic inhibition that mirrored our results obtained with whole-cell BV-2 homogenates (Fig. 2A, supplemental Fig. 2, available at www.jneurosci.org as supplemental material). Together, these results show that MGL and the novel MGL activity may exhibit distinct subcellular distributions depending on cell

\section{[H-2-AGhyddysis byBV-2 - PH-2-AGhydrdysis by nerans}

\section{$\triangle$ PHF-AEAhycrdysis byBV-2}
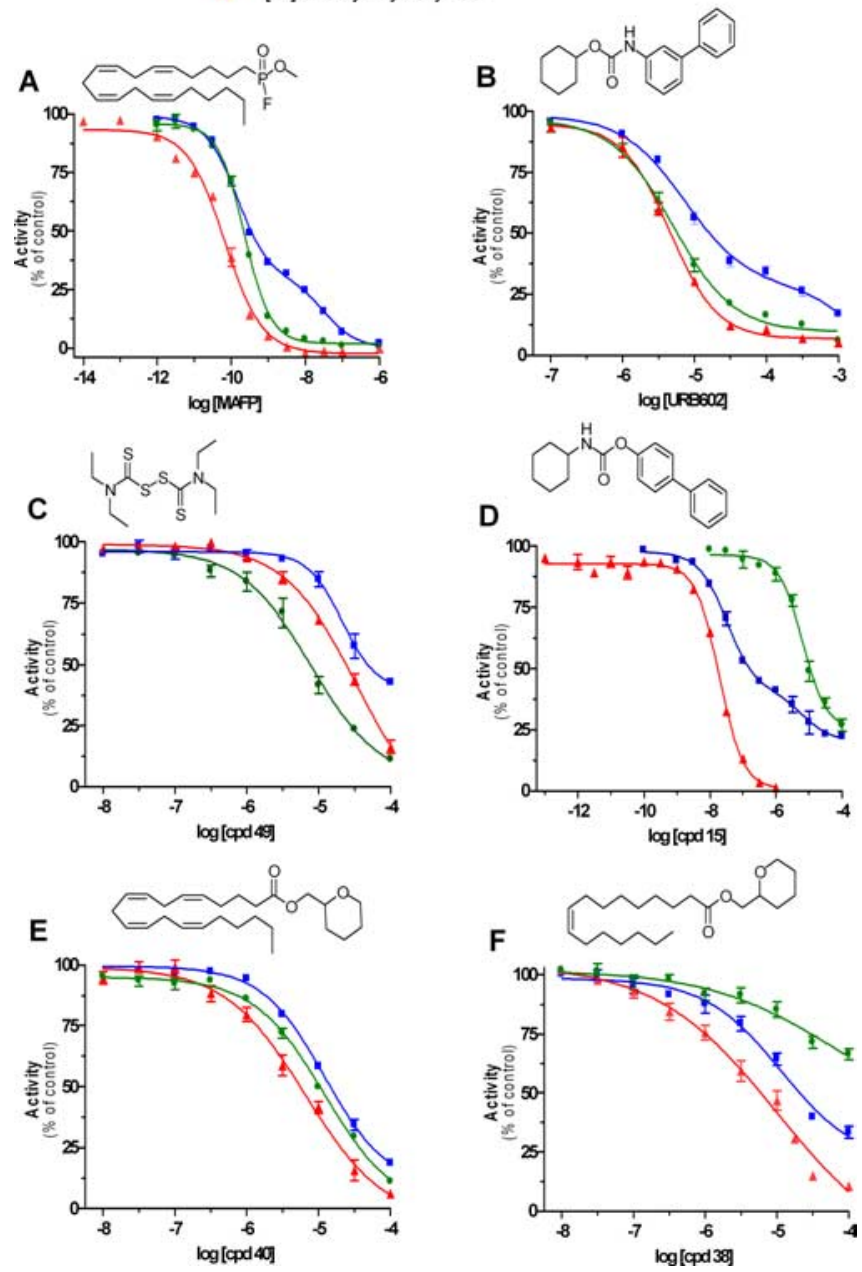

Figure 2. Pharmacological distinction of the novel MGL, MGL, and FAAH. $\boldsymbol{A}, \boldsymbol{B}$, Effect of increasing concentrations of the MGL inhibitors MAFP $(\boldsymbol{A})$ and URB602 $(\boldsymbol{B})$ on $\left[{ }^{3} \mathrm{H}\right]-2$ - $\mathrm{AG}$ hydrolysis by BV-2 ([ $\left.{ }^{3} \mathrm{H}\right]-2-\mathrm{AG}$ by BV-2; blue) and primary neuron $\left(\left[{ }^{3} \mathrm{H}\right]-2-\mathrm{AG}\right.$ by neurons; green) homogenates and on [ $\left.{ }^{3} \mathrm{H}\right]-\mathrm{AEA}$ hydrolysis by $\mathrm{BV}-2\left({ }^{3} \mathrm{H}\right]-\mathrm{AEA}$ by BV-2; red) homogenate. Values are mean \pm SEM (3 experiments performed in duplicate) and are expressed as percentage of control. $\boldsymbol{C}-\boldsymbol{E}$, Effect of increasing concentrations of thiuram disulfide $49(\boldsymbol{C})$, carbamate derivative $15(\boldsymbol{D})$, and tetrahydropyran-2-yl methyl ester derivatives $40(\boldsymbol{E})$ and $38(\boldsymbol{F})$ on $\left[{ }^{3} \mathrm{H}\right]-2-\mathrm{AG}$ hydrolysis by BV-2 ([ $\left.{ }^{3} \mathrm{H}\right]-2-\mathrm{AG}$ by BV-2; blue) and primary neuron $\left(\left[{ }^{3} \mathrm{H}\right]-2-\mathrm{AG}\right.$ by neurons; green) homogenates and on $\left[{ }^{3} \mathrm{H}\right]$-AEA hydrolysis by $\mathrm{BV}-2\left(\left[{ }^{3} \mathrm{H}\right]-\mathrm{AEA}\right.$ by $\mathrm{BV}-2$; red) homogenate. Values are mean \pm SEM ( 3 experiments performed in duplicate) and are expressed as percentage of control. 
A

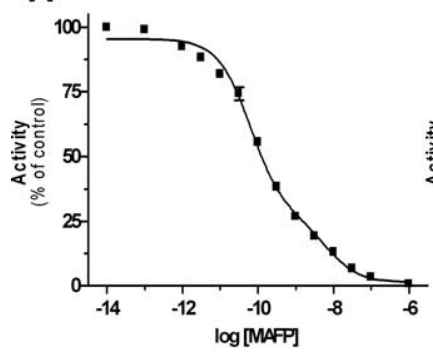

B

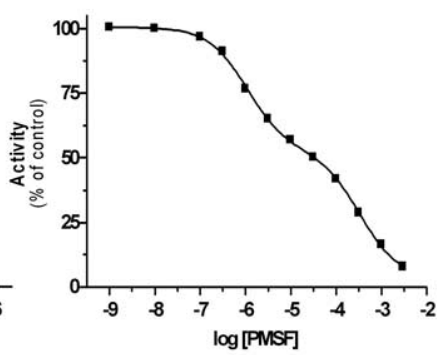

C
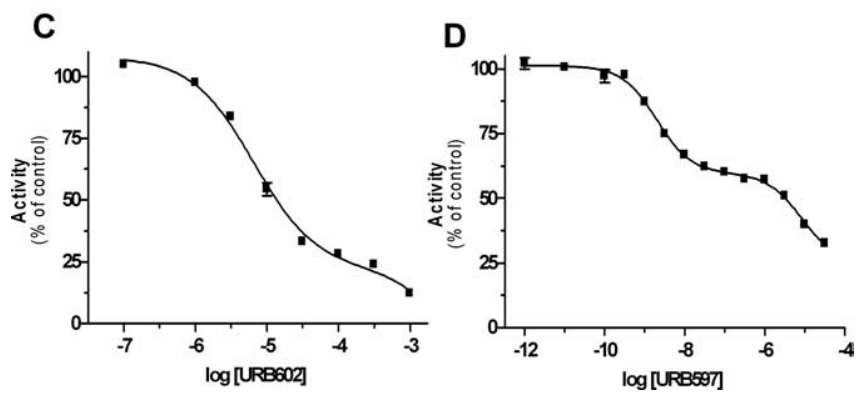

Figure 3. Pharmacological characterization of 2-AG hydrolysis by primary microglia. Effect of increasing concentrations of $\operatorname{MAFP}\left(\boldsymbol{A} ; \mathrm{IC} \mathrm{C}_{50}\right.$ values are 0.07 and $\left.6.7 \mathrm{~nm}\right), \operatorname{PMSF}\left(\boldsymbol{B} ; \mathrm{IC}_{50}\right.$ values are 1.1 and $334 \mu \mathrm{M}), \operatorname{URB} 602\left(\boldsymbol{C} ; \mathrm{IC}_{50}\right.$ values are $6.5 \mu \mathrm{m}$ and $\left.18 \mathrm{~mm}\right)$, and URB597 (D; I $\boldsymbol{C}_{50}$ values are $1.9 \mathrm{~nm}$ and $8.4 \mu \mathrm{m})$, on $\left[{ }^{3} \mathrm{H}\right]-2-A G$ hydrolysis by $10 \mu \mathrm{g}$ of primary microglia homogenates. Values are mean \pm SEM (3 experiments performed in duplicate) and are expressed as percentage of control.

type, and 2-AG hydrolysis by BV-2 mitochondrial fraction involves both FAAH and the novel MGL.

Considering the subcellular distribution of the novel MGL activity, we sought to determine whether its inhibition would lead to 2-AG accumulation in intact cells. Thus, we incubated BV-2 cells in culture with MAFP, URB597, and URB602 and measured 2-AG and anandamide levels by GC/MS. We found that MAFP increased both 2-AG and anandamide by twofold to threefold, whereas URB602 selectively increased 2-AG by sixfold (Fig. 5). URB597 selectively increased anandamide by threefold (Fig. 5). This result suggests that pharmacological inhibition of the novel MGL activity leads to accumulation of 2-AG without affecting anandamide levels, and confirms previous studies showing that pharmacological inhibition of FAAH leads to the accumulation of anandamide without affecting 2-AG levels.

\section{Discussion}

We provide evidence for the existence of a previously undescribed MGL activity that controls 2-AG levels in intact microglial cells, is enriched in mitochondrial and nuclear fractions, and can be pharmacologically distinguished from the cloned MGL and FAAH.

Similar to FAAH and MGL, the novel MGL activity likely belongs to the family of serine hydrolases because it is sensitive to both MAFP and PMSF. We found several compounds that differentially inhibited MGL, FAAH, and the novel MGL. URB602, MAFP, and the thiuram disulfide are better inhibitors of MGL than of the novel MGL activity, whereas PMSF is a better inhibitor of the novel MGL than of MGL. Note that although the apparent potency of URB602 toward the novel MGL is low, at 100 $\mu \mathrm{M}$ it increased 2-AG levels by sixfold in intact BV-2 cells without affecting anandamide levels. Compounds 40 and 38 also differentially inhibited MGL and the novel MGL in a manner suggesting that MGL is more sensitive to changes in the acyl chain of acyl

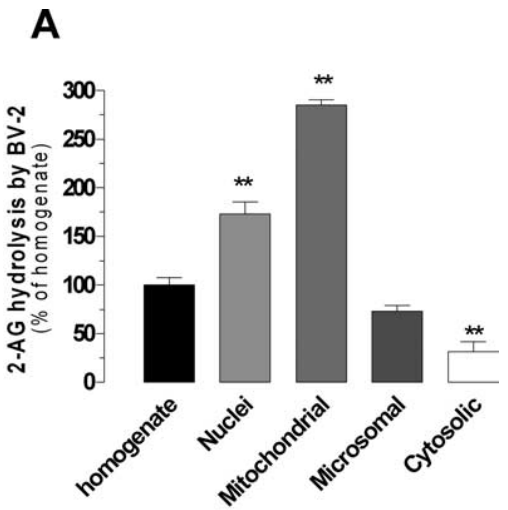

B

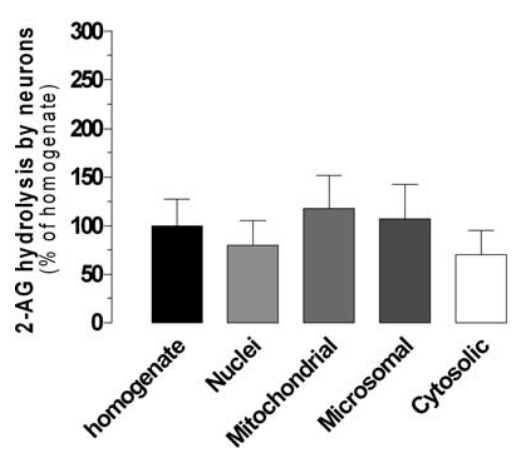

Figure 4. Subcellular distribution of 2-AG hydrolysis in BV-2 cells and neurons. A, B, Subcellular fractions (nuclei, mitochondrial, microsomal, and cytosolic) and the crude homogenate of BV-2 cells $(\boldsymbol{A})$ and primary neurons $(\boldsymbol{B})$ were assayed for $\left[{ }^{3} \mathrm{H}\right]-2-\mathrm{AG}$ hydrolysis $(\approx 55,000 \mathrm{dpm})$ in the presence of 200 and $250 \mu \mathrm{m} 2-\mathrm{AG}$, respectively (to saturate enzymatic activities). Activities in fractions were normalized to the crude homogenate activity. Values are the mean \pm SEM of three experiments performed in duplicate. ${ }^{* *} p<0.01$ (ANOVA followed by Dunnett's post-test).

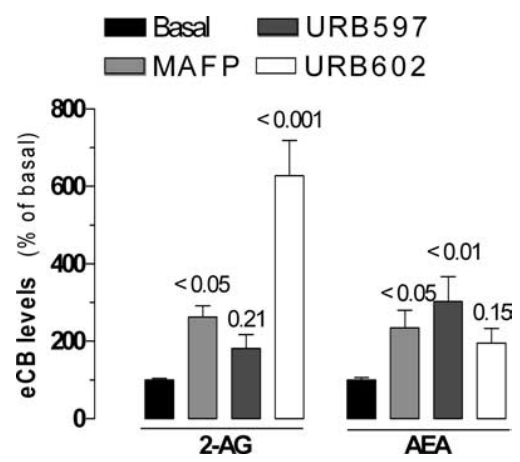

Figure 5. MAFP, URB597, and URB602 differentially affect 2-AG and anandamide levels in intact BV-2 cells. BV- 2 cells $\left(3 \times 10^{6} /\right.$ dish) were incubated $\left(37^{\circ} \mathrm{C}\right)$ with MAFP $(1 \mu \mathrm{m})$, URB597 (100 nM), URB602 (100 $\mu \mathrm{M})$, or 0.1\% DMSO (basal) for 20 min before lipid extraction and eCB quantification by $\mathrm{Cl}-\mathrm{GC} / \mathrm{MS}$. 2-AG and anandamide levels are compared with their respective basal levels and are the mean of four to five experiments performed in duplicate (i.e., 8-10 dishes per condition) \pm SEM. ANOVA followed by Dunnett's post-test was used, and the $p$ values are indicated.

ester derivatives than the novel MGL. URB597 and compound 15 differ by the biphenyl moiety orientation and by the polar substituent present on URB597. Such structural differences result in a difference in potency toward FAAH of one order of magnitude, without significantly affecting the potency toward the novel MGL. The preferential inhibitory effect of compound 49 (a thiuram disulfide) toward MGL is in agreement with previous reports 
describing the sensitivity of MGL activity to thiol-modifying agents such as p-chloromercuribenzoic acid, $\mathrm{HgCl}_{2}$, $\mathrm{N}$-ethylmaleimide, and maleimide derivatives (Tornqvist and Belfrage, 1976; Saario et al., 2005). These results provide an insight into the chemical features required for the synthesis of more potent/selective inhibitors of the novel MGL.

URB597 and URB602 appear quite selective in increasing either anandamide or 2-AG, respectively. Nanomolar concentration of URB597 inhibited anandamide hydrolysis in BV-2 cells, whereas micromolar concentration of URB597 inhibited 2-AG hydrolysis in neuronal homogenates. The later result indicates that FAAH is not involved in 2-AG hydrolysis in neuronal homogenates and accordingly no significant $\left[{ }^{3} \mathrm{H}\right]$-anandamide hydrolysis was measured when using $1 \mu \mathrm{g}$ of protein of neuron homogenate $\left(5 \mu \mathrm{g}\right.$ of protein were required to detect $\left[{ }^{3} \mathrm{H}\right]$ anandamide hydrolysis, supplemental Fig. $1 \mathrm{~K}$, available at www. jneurosci.org as supplemental material). Thus, URB597 at 100 $\mathrm{nM}$ inhibited anandamide hydrolysis in BV-2 homogenates and increased anandamide levels by threefold in intact BV-2 cells. Conversely, the same concentration of URB597 also inhibited 2-AG hydrolysis in BV-2 cell homogenates but did not affect 2-AG levels in intact BV-2 cells. This result confirms previous studies showing that although FAAH hydrolyzes 2-AG in homogenates (Goparaju et al., 1998), its pharmacological inhibition in vivo or genetic ablation does not affect 2-AG levels in tissues (Lichtman et al., 2002; Patel et al., 2005). We found that URB602 inhibits anandamide hydrolysis in BV-2 cell homogenate, but it did not affect anandamide levels in intact BV-2 cells, indicating that this inhibitory effect is unlikely to be relevant in intact tissue. Together, these results show that the novel MGL mediates the majority of 2-AG hydrolysis, and the FAAH mediates the majority of anandamide hydrolysis in intact BV-2 cells, and that their selective inhibition induces independent accumulation of 2-AG or anandamide, respectively.

The novel MGL is enriched in mitochondria and nuclei, and its inhibition led to 2-AG accumulation in intact cells. This result is reminiscent of what has been reported for FAAH, because the latter enzyme is enriched in the reticulum of cells, and its inhibitors efficiently induce anandamide accumulation (Gulyas et al., 2004). Accordingly, we found that 2-AG hydrolysis by BV-2 mitochondrial fraction involves both FAAH and the novel MGL. How differences in the subcellular distribution of eCB hydrolyzing enzymes between species and tissue control the efficacy of eCB signaling remains unknown.

In a previous study, we had found that mouse primary microglia in culture express MGL mRNA and hydrolyze 2-AG (Witting et al., 2006). We now show that 2-AG hydrolysis by primary microglia is inhibited with the same pharmacological profile as 2-AG hydrolysis by BV-2 cells, suggesting that both FAAH and the novel MGL also mediate 2-AG hydrolysis in primary microglia. Interestingly, these results also suggest that the cloned MGL, which is thought to be responsible for the majority of the 2-AG hydrolysis in healthy brain (Hohmann et al., 2005), does not play a major role in primary microglia. Possible explanations include cell-specific regulation of MGL translation that would keep MGL mRNA present and little or no MGL protein expressed. Furthermore, it is likely that cytokines and allied microglia activation differentially regulate the expression of MGL and the novel MGL and that their relative involvement in 2-AG hydrolysis in healthy and diseased brain is different. Indeed, we had found that IFN $\gamma$ (interferon- $\gamma$ ) increases 2-AG hydrolysis in primary microglial cells and reduces their MGL mRNA expression, suggesting an inverse regulation of both enzymes by this cytokine (Witting et al., 2006). A better understanding of how microglia activation sets the relative expression of MGL and the novel MGL, and the extent to which these enzymes contribute to $2-A G$ degradation in healthy and inflamed brain, awaits the molecular identification of the novel MGL.

Finally, the existence of a novel, pharmacologically distinct, MGL opens promising therapeutic avenues. Indeed, it is likely that the chemical platform required for the selective inhibition of the novel MGL is different from the one required for selective inhibition of MGL and FAAH. It is also likely that selective inhibition of the novel MGL will lead to different cannabimimetic effects in vivo compared with those induced by selective FAAH and MGL inhibitors. Directly testing these possibilities will require the identification of specific inhibitors of the novel MGL, as well as its cloning and characterization at the molecular level.

\section{References}

Baker D, Pryce G, Croxford LJ, Brown P, Pertwee RG, Makriyannis A, Khanolkar A, Layward L, Fezza F, Bisogno T, DiMarzo V (2001) Endocannabinoids control spasticity in a multiple sclerosis model. FASEB J 15:300-302.

Bisogno T, Howell F, Williams G, Minassi A, Cascio MG, Ligresti A, Matias I, Schiano-Moriello A, Paul P, Williams EJ, Gangadharan U, Hobbs C, Di Marzo V, Doherty P (2003) Cloning of the first sn 1-DAG lipases points to the spatial and temporal regulation of endocannabinoid signaling in the brain. J Cell Biol 163:463-468.

Cravatt BF, Lichtman AH (2003) Fatty acid amide hydrolase: an emerging therapeutic target in the endocannabinoid system. Curr Opin Chem Biol 7:469-475

Cravatt BF, Saghatelian A, Hawkins EG, Clement AB, Bracey MH, Lichtman $\mathrm{AH}$ (2004) Functional disassociation of the central and peripheral fatty acid amide signaling systems. Proc Natl Acad Sci USA 101:10821-10826.

Di Marzo V, Bisogno T, De Petrocellis L, Melck D, Orlando P, Wagner JA, Kunos G (1999) Biosynthesis and inactivation of the endocannabinoid 2-arachidonoylglycerol in circulating and tumoral macrophages. Eur J Biochem 264:258-267.

Dinh TP, Carpenter D, Leslie FM, Freund TF, Katona I, Sensi SL, Kathuria S, Piomelli D (2002) Brain monoglyceride lipase participating in endocannabinoid inactivation. Proc Natl Acad Sci USA 99:10819-10824.

Dinh TP, Kathuria S, Piomelli D (2004) RNA interference suggests a primary role for monoacylglycerol lipase in the degradation of the endocannabinoid 2-arachidonoylglycerol. Mol Pharmacol 66:1260-1264.

Dupont R, Goossens JF, Cotelle N, Vrielynck L, Vezin H, Hénichart JP, Cotelle P (2001) New bis-catechols 5-lipoxygenase inhibitors. Bioorg Med Chem 9:229-235.

Fegley D, Gaetani S, Duranti A, Tontini A, Mor M, Tarzia G, Piomelli D (2005) Characterization of the fatty acid amide hydrolase inhibitor cyclohexyl carbamic acid 3'-carbamoyl-biphenyl-3-yl ester (URB597): effects on anandamide and oleoylethanolamide deactivation. J Pharmacol Exp Ther 313:352-358.

Freund TF, Katona I, Piomelli D (2003) Role of endogenous cannabinoids in synaptic signaling. Physiol Rev 83:1017-1066.

Ghafouri N, Tiger G, Razdan RK, Mahadevan A, Pertwee RG, Martin BR, Fowler CJ (2004) Inhibition of monoacylglycerol lipase and fatty acid amide hydrolase by analogues of 2-arachidonoylglycerol. Br J Pharmacol 143:774-784.

Gobbi G, Bambico FR, Mangieri R, Bortolato M, Campolongo P, Solinas M, Cassano T, Morgese MG, Debonnel G, Duranti A, Tontini A, Tarzia G, Mor M, Trezza V, Goldberg SR, Cuomo V, Piomelli D (2005) Antidepressant-like activity and modulation of brain monoaminergic transmission by blockade of anandamide hydrolysis. Proc Natl Acad Sci USA 102:18620-18625.

Goparaju K, Natsuo U, Yamaguchi H, Yamamoto S (1998) Anandamide amidohydrolase reacting with 2-arachidonoylglycerol, another cannabinoid receptor ligand. FEBS Lett 422:69-73.

Goparaju SK, Ueda N, Taniguchi K, Yamamoto S (1999) Enzymes of porcine brain hydrolyzing 2-arachidonoylglycerol, an endogenous ligand of cannabinoid receptors. Biochem Pharmacol 57:417-423.

Gulyas AI, Cravatt BF, Bracey MH, Dinh TP, Piomelli D, Boscia F, Freund TF (2004) Segregation of two endocannabinoid-hydrolyzing enzymes into 
pre- and postsynaptic compartments in the rat hippocampus, cerebellum and amygdala. Eur J Neurosci 20:441-458.

Hohmann AG, Suplita RL, Bolton NM, Neely MH, Fegley D, Mangieri R, Krey JF, Walker JM, Holmes PV, Crystal JD, Duranti A, Tontini A, Mor M, Tarzia G, Piomelli D (2005) An endocannabinoid mechanism for stress-induced analgesia. Nature 435:1108-1112.

Karlsson M, Contreras JA, Hellman U, Tornqvist H, Holm C (1997) cDNA cloning, tissue distribution, and identification of the catalytic triad of monoglyceride lipase. Evolutionary relationship to esterases, lysophospholipases, and haloperoxidases. J Biol Chem 272:27218-27223.

Karlsson M, Reue K, Xia YR, Lusis AJ, Langin D, Tornqvist H, Holm C (2001) Exon-intron organization and chromosomal localization of the mouse monoglyceride lipase gene. Gene 272:11-18.

Kathuria S, Gaetani S, Fegley D, Valino F, Duranti A, Tontini A, Mor M, Tarzia G, La Rana G, Calignano A, Giustino A, Tattoli M, Palmery M, Cuomo V, Piomelli D (2003) Modulation of anxiety through blockade of anandamide hydrolysis. Nat Med 9:76-81.

Kozak KR, Rowlinson SW, Marnett LJ (2000) Oxygenation of the endocannabinoid, 2-arachidonylglycerol, to glyceryl prostaglandins by cyclooxygenase-2. J Biol Chem 275:33744-33749.

Kozak KR, Gupta RA, Moody JS, Ji C, Boeglin WE, DuBois RN, Brash AR, Marnett LJ (2002) 15-Lipoxygenase metabolism of 2-arachidonylglycerol. Generation of a peroxisome proliferator-activated receptor alpha agonist. J Biol Chem 277:23278-23286.

Leung D, Saghatelian A, Simon GM, Cravatt BF (2006) Inactivation of $\mathrm{N}$-acyl phosphatidylethanolamine phospholipase D reveals multiple mechanisms for the biosynthesis of endocannabinoids. Biochemistry 45:4720-4726.

Lichtman AH, Hawkins EG, Griffin G, Cravatt BF (2002) Pharmacological activity of fatty acid amides is regulated, but not mediated, by fatty acid amide hydrolase in vivo. J Pharmacol Exp Ther 302:73-79.

Liu J, Wang L, Harvey-White J, Osei-Hyiaman D, Razdan R, Gong Q, Chan AC, Zhou Z, Huang BX, Kim HY, Kunos G (2006) A biosynthetic pathway for anandamide. Proc Natl Acad Sci USA 103:13345-13350.

Maejima T, Oka S, Hashimotodani Y, Ohno-Shosaku T, Aiba A, Wu D, Waku K, Sugiura T, Kano M (2005) Synaptically driven endocannabinoid release requires $\mathrm{Ca}^{2+}$-assisted metabotropic glutamate receptor subtype 1 to phospholipase $\mathrm{C} \beta 4$ signaling cascade in the cerebellum. J Neurosci 25:6826-6835.

Makara JK, Mor M, Fegley D, Szabo SI, Kathuria S, Astarita G, Duranti A, Tontini A, Tarzia G, Rivara S, Freund TF, Piomelli D (2005) Selective inhibition of 2-AG hydrolysis enhances endocannabinoid signaling in hippocampus. Nat Neurosci 8:1139-1141.

McKinney MK, Cravatt BF (2005) Structure and function of fatty acid amide hydrolase. Annu Rev Biochem 74:411-432.

Mentlein R, Suttorp M, Heymann E (1984) Specificity of purified monoacylglycerol lipase, palmitoyl-CoA hydrolase, palmitoyl-carnitine hydrolase, and nonspecific carboxylesterase from rat liver microsomes. Arch Biochem Biophys 228:230-246.

Mitchell JA, Akarasereenont P, Thiemermann C, Vane JR (1993) Selectivity of nonsteroidal antiinflammatory drugs as inhibitors of constitutive and inducible cyclooxygenase. Proc Natl Acad Sci USA 90:11693-11697.

Moody JS, Kozak KR, Ji C, Marnett LJ (2001) Selective oxygenation of the endocannabinoid 2-arachidonylglycerol by leukocyte-type 12lipoxygenase. Biochemistry 40:861-866.

Okamoto Y, Morishita J, Tsuboi K, Tonai T, Ueda N (2004) Molecular characterization of a phospholipase $\mathrm{D}$ generating anandamide and its congeners. J Biol Chem 279:5298-5305.

Patel S, Carrier EJ, Ho WS, Rademacher DJ, Cunningham S, Reddy DS, Falck JR, Cravatt BF, Hillard CJ (2005) The postmortal accumulation of brain $\mathrm{N}$-arachidonylethanolamine (anandamide) is dependent upon fatty acid amide hydrolase activity. J Lipid Res 46:342-349.

Saario SM, Salo OM, Nevalainen T, Poso A, Laitinen JT, Jarvinen T, Niemi R (2005) Characterization of the sulfhydryl-sensitive site in the enzyme responsible for hydrolysis of 2-arachidonoyl-glycerol in rat cerebellar membranes. Chem Biol 12:649-656.

Simon GM, Cravatt BF (2006) Endocannabinoid biosynthesis proceeding through glycerophospho-N-acyl ethanolamine and a role for alpha/betahydrolase 4 in this pathway. J Biol Chem 281:26465-26472.

Somma-Delpéro C, Valette A, Lepetit-Thévenin J, Nobili O, Boyer J, Vérine A (1995) Purification and properties of a monoacylglycerol lipase in human erythrocytes. Biochem J 312:519-525.

Stella N, Pellerin L, Magistretti P (1995) Modulation of the glutamateevoked release of arachidonic acid from mouse cortical neurons: involvement of a pH-sensitive membrane phospholipase A2. J Neurosci 15:3307-3317.

Stella N, Schweitzer P, Piomelli D (1997) A second endogenous cannabinoid that modulates long-term potentiation. Nature 388:773-778.

Sun YX, Tsuboi K, Okamoto Y, Tonai T, Murakami M, Kudo I, Ueda N (2004) Biosynthesis of anandamide and N-palmitoylethanolamine by sequential actions of phospholipase A2 and lysophospholipase D. Biochem J 380:749-756.

Tarzia G, Duranti A, Tontini A, Piersanti G, Mor M, Rivara S, Plazzi PV, Park C, Kathuria S, Piomelli D (2003) Design, synthesis, and structureactivity relationships of alkylcarbamic acid aryl esters, a new class of fatty acid amide hydrolase inhibitors. J Med Chem 46:2352-2360.

Tornqvist H, Belfrage P (1976) Purification and some properties of a monoacylglycerol-hydrolyzing enzyme of rat adipose tissue. J Biol Chem 251:813-819.

Walter L, Stella L (2003) Endothelin-1 increases 2-arachidonyl glycerol (2AG) production in astrocytes. Glia 44:85-90.

Walter L, Franklin A, Witting A, Möller T, Stella N (2002) Astrocytes in culture produce anandamide and other acylethanolamides. J Biol Chem 277:20869-20876.

Walter L, Franklin A, Witting A, Wade C, Xie Y, Kunos G, Mackie K, Stella N (2003) Non-psychotropic cannabinoid receptors regulate microglial cell migration. J Neurosci 23:1398-1405.

Witting A, Chen L, Cudaback E, Straiker A, Walter L, Rickman B, Moller T, Brosnan C, Stella N (2006) Experimental autoimmune encephalomyelitis disrupts endocannabinoid-mediated neuroprotection. Proc Natl Acad Sci USA 103:6362-6367. 